\title{
The Development of the Ash'arite Doctrine in North Africa: Building of Theological, Political and Religious Unity
}

\author{
Dr. Tarek Ladjal
}

Effat University. Jeddah

Kingdom of Saudi Arabia

\section{Doi:10.5901/ajis.2015.v4n3p291}

\begin{abstract}
Understanding the socio-cultural identity of contemporary North Africa (Maghreb) and the background of much of its political development should not be held away from its religious, theological and juristic history. The reason being that neglect of the religious history of the region only obscures our vision of the real driving forces shaping much of today's religious and cultural progress in the Maghreb. This study examines the historical stages and characteristics of the Ash'arite intellectual development in the Maghreb while exploring factors contributing to the shaping of its intellectual unity. The scope of this inquiry is to examine the historical and intellectual evolution of Asharism in the Maghreb; some of its profound implications on society, religious instruction, and eventually the political history of the region will also be inspected. This research touches on fundamental evolutionary stages in the formation and consolidation of Ash'arism in the Maghreb, each of which exerts socio-political implications on the region while also reflecting the intellectual, political and cultural interaction with the Muslim East. This research is instrumental to the understanding of the efforts made by respective governments in the Maghreb to strengthen Ash'arism to preserve viable and sustainable unity between Muslims in the region.
\end{abstract}

Keywords: Abu al-Hasan al-Ash‘ari. Ash‘arism. Maghreb. Malikism. Muslim East. Almohads Dynasty

\section{Introduction}

The rise of Abu al-Hasan al-Ash'ari (874-936) in the fourth century represents a turning point in the historical development of religious and intellectual unity for Muslims; it is so perhaps because of the volatile intellectual life, particularly following the conflicts arising between the Hijazi 'Alawites and the Levantine Umayyad. Their conflict took place following the emergence of Muslim scholastic theology ('ilm al-kalam), which is still unclear for the People of hadith (ahl al-hadith). As such, the emergence of Ash'arism at such juncture was critical to the growth and development of religious, theological and intellectual history of Muslims. In those conditions, the Sunnis were unable to resist any intellectual pressure exerted by the Mu'tazilite government-backed campaign. This study does not strictly follow a chronological historical sequence leading to the birth of Ash'arism as most of these incidents are known in current academic research (al-'Urwi 1994; Saghir 2005; al-Idrisi; al-Tumami 2004). Instead, it chooses to discuss the main characteristics of Ash'arism which spread throughout the Islamic world. As such it paves the way for exploring a number of its intellectual features while pointing out the critical ideologies that contributed to the formation of Ash'arism.

The development of Ash'arism according to Ibn Khaldun (d. 1406) has occurred in three consecutive stages, each of which was affected by certain prominent scholarly figure. The first is the stage of Baqillani (d. 1013), who developed a rational methodology and set the founding ground for intellectual proofs and preambles that represent later the fundamental basis of Ash'arism. The second is Abu al-Hasan al-Ash'ari who layed the general foundations of the Ash'arism. Al-Juwaini (d.1085) however led Ash'arism in Baqillani's footsteps and introduced his work 'al-Shamil' (The Comprehensive) (Ibn Khaldun 2004), which he summarized later into 'al-Irshad' (The Guide) (Ibn Khaldun 2004). His work further reinforced the Ash'arite ideology in the Maghreb. Al-Juwaini also developed some new ideas that have not been discussed earlier in the Ash'arite School. Fakhr al-Din al-Razi (d.1209) on the other hand intergrated philosophy and logic with scholastic theology; his work reflects the nature of the period during which the Islamic philosophy was at its peak. This forced Ash'arite scholars to engage with the philosophical issues and problems so as to address inquiries of philosophy (Ibn Khaldun 2004). 


\section{Survey of the Intellectual History in the Maghreb Prior to the $12^{\text {th }}$ Century}

Because of its remote geographic location from the centre of the Islamic Caliphate, the Maghreb represented a safe haven for intellectual and political views opposing the central government in Damascus and Baghdad. That caused increased migrations of intellectual and political opposition since the Seventh Century searching for security from government persecution, and as a result, the intellectual and political conditions of the Maghreb become unstable since the early centuries of Islam. In the second half of the eighth century for instance (Bel 1938), the Maghreb became completely independent from the direct administration of the Abbasside Caliphate, and was divided into four states namely the Sunni Andalusia (756-1031), the Sunni Aghlabids Dynasty (800-909) known today as Tunisia, the Ibadi Rustamid Dynasty (776-909) in Algeria, and the Idrisid Dynasty (788-974) seen back then as the hope for Shi'ites fleeing Abbasids' persecution (Bel 1938).

The political disintegration in the Maghreb caused yet another intellectual breakdown based on the very ideologies of the the Sunni Aghlabids, the Khariji Rustamids and the Shiti Idrisids in addition to some others groups who settled in the region for similar reasons. The Isma'ilis perhaps were the most visible group; they succeeded to build an independently autonomous polity in Algeria between the years of 909-1171; their system grew stronger thus putting an end to the Sunni Aghlabids Dynasty in Tunisia in 909 (Abu al-Nasr 1987). As a result, the Shiites began to spread to the North and have, consequently, occupied Egypt in 935, as well as the Hijaz and most of Sham (Levant), and have as such established the Fatimid Caliphate. Such diverse and politically disurbing conditions based on theological and ideological differences in the Maghreb lasted for a considerable period of time; witnessing yet another type of conflict, this time, between the Maliki and Hanafi Schools of law in competion for the region's control.

It was only after the Fatimids' eventual return to the East with the shift of authority to the Berber Zirid Dynasty (9731152) that the Maghreb started to witness the beginning of theological stability. Following an assurance of the non-return of the Fatimids back to the Maghreb, the Zirid during the reign of Mu'izz ibn Badis (1016-1062) declared the Maghreb as a Sunni region in the year of 1045(Al-Murrakishi 1999). In spite of their intent to officially form a united theology and ideology in the Maghreb, the territory was still unstable due to the limitations of their authority in the region to the Middle Maghreb (i.e., Algeria) only (al-Nasiri 1997).

One of the striking development in the ideological and theological history of the Maghreb however, began with the rise of the Almoravids (1040-1147), who appeared during the rise of an Eastern Ash'arite ideology, namely that of Abu alHasan al-Ash'ari, which had then started to spread as a resut of the wane of Mu'tazilim and the withdrawal of Batinism (batiniyyah)( Abid al-Jabiri 1993). This was, in part, because of the power of the Sunni Seljuq State (1016-1153 C.E), which reinforced its ideological and political control over the central Caliphate and the East (O'Brien 2010, 87) under the auspice and guidance of Nizam al-Mulk (d.1092) (Hodgson 1958), which further encouraged and supported theologians like Al-Juwaini (d.1085), Al-Ghazali (d.1111), Al-Qushayri (d. 1072), and some others outstanding scholars against Mu'tazilites and Batinism. These developments were also associated with a unity of theological and political powers in the Maghreb showing thus remarkable contrast with the East, where the Shi'ite alongside other ideas and groups managed to maintain their existence and power.

The Almoravids' political power at the time of the first emergence of Ash'arite ideology in the Maghreb, was guided by simplicity of life; their ideology and theology, however, contributed to undermining if not elimination, of all ideological remnants in the region. They fought against other religious ideologies, and sometimes even harshly persecuted their opponents (al-Urwi 1994). Their ideological frame of empire building, however, was ill-defined due to a number of factors, the discussion of which falls beyond the boundaries of this paper. Perhaps the most noteworthy of those factors, and one that must be mentioned here, is the co-occurrence of Ash'arism in both the Maghreb and Andalusia with the Almoravid Empire where the Ash'arite School was deeply engrained in the hearts and minds of the intelligensia and the masses alike (Skali 2007).

\section{Spread of Ash'Arism in the Maghreb}

Historians debate the exact date of the rise of Ash'arism and the stages of its historical development. However, examination of the historical stages of this school of thought points to the following three main historical stages:

\subsection{Early Introduction}

This stage is signficantly marked by efforts of individuals who sought to spread the ideology of Ash'arism in the Maghreb. 
This was limited to scholars who upon return from their intellectual journeying in the East under the guidance of Ash'arite scholars, have carried with them new intellectual and theological persusasions lacking any official political support or endorsment. Researchers do not agree on who was the first person to introduce Ash'arism to the Maghreb, and cannot agree either on the point in history when it happened. Most concede that it was during the tenth Century during the lifetime of Abu al-Hasan al-Ash'ari. Some, however, argue that it was the Tunisian scholar Ibrahim ibn Abdullah al-Zabidi or al-Zubayri, also known as al-Qalanisi (d. 969) (Alawi 2008), whereas still others claim it was that Abu Maymun Daris ibn Isma'il al-Fasi (d. 967) (Harakat 2000). Despite these differences, however, there has been a recent consensus among historians pointing to Abu al-Hasan al-Kabisi (d.1012) as the first to introduce Ash'arism into the Maghreb.

As a result of the introduction of Ash'arism, a number of scholars embraced it and contributed to its dissemination. Some of them travelled to the East and learned under famous Ash'arite scholars to return back to the Maghreb to spread the doctrine of Ash'ariyyah. Among them one finds Abu 'Abdullah al-Azdi (d. 1030) and Abu Ùahir al-Baghdadi (d.1056) (Alawi 2008), who both learned theology under al-Baqillani, who directed them to head westward, to the Maghreb and Andalus, and to spread Ash'arism (Ibn 'Asakir 2000; Iyaa 2000). One also finds other important key figures like Abu 'Umar al-Talamanki (d.1037), Abu Imran al-Fasi (d.1038) and Abu al-Walid al-Baji (d.1081) (Abd al-Aziz 1975), whose endeavour to sprea Ash'arism was particularly difficult in its early stages, perhaps because of the Bedouin nature of the Almoravids, who were raised in the Sahara away from the complexity of life experienced in the North.

The Ash'arites endured a significant amount of trouble on the part of Almoravid scholars, who felt that their dynasty and way of life were threatened by imminent spread of Ash'arism. In spite of this however, there was a number of competent Ash'arite scholars and intellectuals who were close to the Muslim masses, including Abu 'Imran al-Fasi (d.1038), who led and supported the Maliki School of law. Al-Fasi was known as one of the scholars who influenced Andalusia and the Maghreb while playing a significant role in the establishment of the Almoravid Dynasty (Sallabi 2003). There was also Abu Bakr Muhammad ibn al-Hasan al-Muradi (d.1096), the author of 'al-ishara ila adab al-imara' (on the ethics of governance), Abu al-Tayib Sa'id ibn Ahmad al-Asfaqsi (d. 1107), a scholar from Tunisia, author of 'al-Aqidah alAsfaqsiyyah' (The Asfaqisi Theology). This stage of introduction lasted up until the end of the Almoravids in 1147 (alSaghir 2005).

\subsection{The descent of the Almoravids to the Almohads dynasty (1121-1269):}

The decline of Almoravids at the hands of Mahdi ibn Tumart (d.1130) was a turning point in the history of the ideological development of the Maghreb, as well as a pivotal change in its intellectual, legal and political unity. The reason being that ibnTumart was a strict Ash'arite scholar, trained in the East at the hands of pioneer Ash'arite scholars like Abu Hamid alGhazali (al-Șinhaji Bayaaq 1971). Ibn Tumart wrote "aqidat al-murshidah', which attracted increasing attention of scholars, and was considered as a manifest of his Ash'arism (al-Najjar 1999). IbnTumart taught the public the principles of his new theological ideology, causing therefore positive impact in the spread of Ash'arism and has, as such, led people to dissociate themselves form previous schools of thought and theology known back then as "aqidat ahl al-taslim wa altafwid" (submission to God) ${ }^{1}$. This is shown in the number of scholars and intellectuals who declared Ash'arism as their theological ideology after Ibn Tumart, stood for it, and developed it through their teaching and works. Unfortunately, IbnTumart did not live long to witness the harvest of his efforts as he died prior the culmination of his dynasty. His ideas and principles however, continued on after his death and were maintained by his successors who endeavoured to make the Ash'arite school the official ideology in the Maghreb as means for acquiring political power (Al-Najjar , 1999; Allam 1964).

With the establishment of the Almohads Dynasty, a new stage of official Ash'arite theorization began. It was perhaps for this reason, that scholars of Ash'arite persuasions had to equip themselves with methods and arguments to support and qualify their new ideology in the most coherent and systematic form possible. Such measures were taken to ensure the continuity and at the same time consistency of Ash'arism against all sorts of resistance and challenges. Although their path was not well paved, they could substitute existing methods while founding new political order. Among those distinguished intellectuals who contributed to the process of officializing the Ash'arite doctrine in the Maghreb were

\footnotetext{
1 The premise of this creed is a major controversial issue among Muslim sects in regards to the interpretation of the divine attributes of God. Proponents of this creed see the necessity for tafwia (submissiveness or deputization) of knowledge by fact of attributes and its essence to God himself, without dwelling on the meaning, or attempting to understand it. This was the official creed of the Maghreb during the Almoravids and prior the rise of Almohads.
} 
Abu al-Fadly, Ibn al-Naíwi (d.1119), Abu al-Hajjaj Yusuf ibn al-Öarir (d.1126), al-Qadi' Iyyad (d1149), Ibn al-Arabi Mu'afiri (d.1148) and 'Uthman al-Salaliji (d.1178) (al-Najjar 1992).

Perhaps the most famous scholarly figure is Abu al-Hajjaj ibn Musa al-Öarir who learned law and Ash'arism under the renowned jurist Abu Bakr Muhammad al-Muradi, and who produced works on grammar and theology. Following his teacher's death, Öarir assumed his position as a leading figure in the school of Ash'ariyyah (lyaa 1982). Öarir is known for his theolgocal treatise entitled 'al-tanbih wa al-irshad fi 'ilm al-i'tiqad', a didactic poetry in more than one thousand and six hundred verses on the Ash'arite theology written in a simple style for children and beginners (Harakat, II: 321). His works became the primary theological source used in religious learning institutions, and have, as such, significantly contributed to the effective dissemination of the ideology of Ash'arism in the Maghreb (al-Tumami 2004).

Another interesting figure is Abu Bakr ibn al-'Arabi - Andalusian jurist, intellectual, and Ash'arite theologian. His major contribution to the shaping of the theological history of Andalusia and the Maghreb was the spread of a number of Ash'arite primary texts produced originally in the the East such as 'madarik al-'uqul', 'al-burhan fi uSul al-fiqh', 'al-'aqidah al-nizamiyyah', and 'ghiyath al-umam' of al-Juwaini', 'tahafut al-falasifa', 'al-iqtiSad fi al-i'tiqad' and 'shifa' al-ghali' by alGhazali, 'al-awsali', 'al-Jami', 'al-kĺafi', and 'al-jami' al-jali' by Abu Isĺaq al-Isfarayini (Ṭalibi 1997). Ibn al-'Arabi also produced major works on Ash'arism such as 'al-amad al-aqSa bi asma' Allah al-lusna wa sifatih al-'Ulya', 'al-risalah alghurrah fi al-radd 'ala ibn Hazm', 'al-WuSul ila ma'rifat al-uSul', 'al-'awaSim min al-qawaSim', and 'qanun al-ta'wil' (Talibi 1997, 54). As a scholar and theologian, Ibn al-'Arabi had an original understanding of the Ash'arite theology, held his own views on theology and had fervently contributed to the spread of Ash'arism in the Maghreb (Harakat,2000).

The last significant figure perhaps is Abu 'Amr 'Uthman al-Salaliji -a Moroccan Ash'arite theologican and expert in Islamic theology, and no less in scholarly competence than al-Juwayni in the East. His reputation was because of his established knowledge on Ash'arite theology on the one hand, but more importantly because of his significant contribution to the spread of the Ash'arism across the Maghreb on the other hand. One work is reproted to have been authored by him is 'Aqidat al-burhaniyyah fi 'ilm al-uluhiyya' commonly known as al-burhaniyyah or al-salalijiyya (bin Bashkwal 1996). His work played a significant role in further developing and strengthening the Ash'arite ideology in the Maghreb, and carried with it clear reflection of the official Ash'arite theology of the Almohads dynasty. His work covers the basic tenets of the Ash'arite theology which, in spite of brevity and simplicity, attracted great scholarly attention and interpretation by many scholars such as Ibn al-Qailiani (d. 1200), one of his close students, ibn Baziza (d.1263), al-Khaffaf (d.1288), al-Yafirni (d. 1333), al-'Aqbani (d.1408), al-Semlali (d.1477) and al-Tinbukti (Bakhti 2005). Their studies on burhaniyyat al-salalijiyya encouraged Ash'arites to further explore and discover more of its ideology and to trace its origin through following works made on it (Bakhti 2005; Yusuf. 2007).

Despite the fact that this period of intellectual history in the Maghreb witnessed a serious conflict between the Almoravids and those associated with the Almohad's theological school, the Ash'arites continue to experience intense theological argumentations, confrontations, and even bloodshed. The public was indiscrimantly coerced to learn the principles of the Ash'arite theology and their deeds and sayings would not be accepted without learning and practice of the Ash'arite theology (al-'Alawi 1992). This was perhaps one of the significant factors that led to the emergence of specialization of Ash'arite theology in the Maghreb, geared for both levels of life, individual and public. Generally speaking, it was during this time that the triumphant dominance of Ash'arism made theology obligatory upon every mature Muslim, both male and female. The growing dominance however, was for al-Juwaini, especially his two works'alshamil' and 'al-irshad'. Al-Irshad for instance represented a work of authority for many theologians and intellectuals during that period of time, and was approached as a source of epistemology for the Ash'arite theology (Alawi 1992). This impacted most of the following works and made of it a milestone in the progress of Ash'arism in the region.

\subsection{The stage of maturity}

The end of the sixth century and the beginning of the seventh signaled a new beginning for Ash'arism in the Maghreb. This period witnessed the rise of an Ash'arite ideology that introduced theological thought in much detail and produced indepth works focusing on explanations of 'al-irshad' by Juwaini, 'al-tanbih' and 'al-irshad' by Öarir, 'al-murshida' by IbnTumart, and 'al-burhaniyya' by al-Salaliji. It was during that period of time that confrontation of philosophers alongside purification of public oral culture from the remains of theologies like the Mu'tazilites, the Shi'ites and the Kharajites (Ihnana, 2007) also took place. It was also during that period of time that a number of renowned scholars rose like Ibn Khamir al-Sabti (d.1217), Abu 'Abdullah ibn al-MunaSif (d.1223) (al-Maghribi 1995), author of 'al-durrah al-sunniyyah fi alma'alim al-sunniyyah', a didactic poetry of seven thousand verses. Similarly, a number of explanations of Juwaini's work 'al-Irshad fi usul al-i'tiqad'(Harakat, 2000) were introduced and as a result contributed to the synthesis of the salient 
features of Maghrebian Ash'arite thought.

Increased interest in Ash'arism also witnessed extensive writing on theology such as 'al-mihad fi sharl al-irshad' by Abu Bakr al-Qurashi al-Maziri (d. 1135); 'nakt 'ala sharí al-irshad' by Abu Ishaq Ibrahim ibn Dahaq known as ibn alMara'a al-Andalusi (d. 1214), 'kifayat al-Ïlalib al-kalam fi sharí al-irshad' by Abu Yahya al-Idrisi al-Husni (d. 1215), 'al-is'ad fi sharí al-irshad' by 'Abd al-'Aziz ibn Baziza (d. 1263), 'sharl al-irshad' by Abu Bakr ibn Maymun al-Qurtubi (d.1173), and 'iqtillaf al-azhar wa-istikhraj nata'ij al-afkar li taíSil al-bughya wa al-murad min sharí kitab al-irshad' by Abu Bakr Muhammad al-Ishbili (d.1183) (Qabali 1987). The treatise of Irshad appears to have encouraged scholars and intellectuals to produce fine scholarly works on theology, creating thus a cultural and theological atmosphere flavored by Juwaini's scholarship and intellectual position.

However, the most significant development in the history of the Ash'arite ideology was the emergence of Ash'arite scholars who made serious changes to the old style of writing used then by most Ash'arites. One example was al-Imam 'Abdullah ibn Yusuf al-Sanusi (d.1489) who authored several interesting works on theology, astrology, mathematics, Qur'anic exgesis, medicine, Sufism, Íadith and law, covering much of the period's theoretical interests (Sa'd Allah 1999). Sanusi however, gained popularity as a theologian and author of theological works such as al-agidah al-kubra and its explanation (the major creed), al-'aqidah al-wuSta (the middle creed) and its interpretation, al-aqidah al-Sughra and its explanation also known as umm al-barahin or al-'aqidah al-sanusiyyah (mother of proofs), al-'aqida Sughra al-Sughra and its explanation, al-'aqidah al-Sughra Sughra al-Sughra known as al-'aqida al-wajizah or 'aqidat al-nisa', (creed of women), al-muqadimat and its explanation (prolegomena and its explanations), an explanation of 'kifayat al-murid fi 'ilm al-tawlid' by Abu al-'Abbas ibn Abdullah al-Jaza'iri (d.1479), an explanation of 'waSitat al-suluk' by Abu 'Abdullah Muhammad alHawdi (d.1504), an explanation of al-Murshida by ibn Tumart, and an explanation of jawahir al-'ulum by 'Adud al-Din al-lji (al-Malali, 2000 ).

Al-Sanusi, however, remains a genuine adherent and supporter of the Ash'arite theology. He represents one of its renowned leading figures during his era in spite of other better informed rivals like al-Shaykh Abu al-'Abbas ibn Zaki alTilimisani (d.1494). Tilmisani was known for his critical opposition to Sanusi's theological vieowpoints, and according to available biographies many debates were held between them, especially on the problem of the faith of muqallid (emulator of opinion without examination) and the visibility of the non-existent. In those debates, Sanusi held stronger views and wielded sharper intelligence (al-Tilimsani 1908). Because of this perhaps, Sanusi was regarded as one of greatest leaders of Ash'arite theology during his time, as shown in his works on theology, in which he discussed the cultural deficiencies manifested in many ideological and political drawbacks in the Maghreb, such as the fall of Andalusia and the dispersion of the Moors. Eventually, emerged a state of inactivity, imitation, and cessation of ijtihad (Bin Sa'id, 1992). Therefore, Sanusi played an extremely critical role in the revival of theology and fighting against taqlid while reconsidering rationalism as a mandatory pre-requisite for the legitimacy and soundness of Muslim beliefs. This, in return, revived the Ash'arite theology while marking the beginning of a new thelogical renaissance (Elaywan 1996).

It is worth noting however, that the theological works of Sanusi were warmly welcomed and spread widely in the Maghreb as well as to the East. Great interest was shown in the teaching, commentaries, its writing style and placing annotations on the explanations of his works. This resulted in many commentaries such as that on 'aqidat al-sanusi alsughra by Muhammad al-Malali al-Tilmisani (d. 1494), on al-'aqidah al-Sughra by Abu al-Abbas ibn Kaddar al-Rashidi (d. 1544), an explanation by Muhammad al-Ma'mun al-HafSi (d.1627), an explanation by Abu al-Hasan Ali al-Yousi (d.1690), 'al-ghanimah al-kubra bi sharí muqaddimat al-sanusi al-sughra' by Ahmad al-Rahuni al-Tatwani (d.1814) (Harakat, 2000). Annotated versions with comments were made on al-Øughra, the most important being 'lashiyat 'umar al-wazzan alqastantini' (d.1553), 'ĺashiyat Ahmad al-Øaqri' (d.1631), 'lashiyat yalya al-shawi' (d.1684), commentary by Muhammad ibn Abdul Qadiral-Tuwati (d.1703), commentary on 'Sughra al-sanusi' by al-Haj Ahmad Aghit (d.1591). Besides, poetry was composed in favour of 'al-'aqidah al-Sughra' such as that of 'Ali ibn Ahmad al-Haj al-Madrasi (d. 1551), Muhammad ibn 'Abd al-Qadir al-Fasi (d.1684), and Muhammad ibn Aghid al-Zaydi (d.1711) (Harakat, 2000). The 'al-'agidah alSughra' produced such magnificient attention, so did 'al-'aqidah al-kubra and al-wusta'. In fact, Sanusis theological writings inspired further writings on Ash'arite theology (Ihnana, 2007).

On the educational level, however, Sanusi's works on theology were taken as the primary source on many levels of theological and institutional discourse. As such, classes and legal opinions on theology have reflected the essence of Sanusi's Ash'arite based-ideology. Dominance of his theology continues up until today, and it continues to be taurght in universities, colleges, and learning centers in the Maghreb, and in Egypt, Iraq, Malaysia, Indonesia and other Muslim countries in which Ash'arism is the official and public theology (Ihnana, 2007). 


\section{Characteristcs of Ash'Arite Thought in the Maghreb}

In the previous section we surveyed some of the developmental stages of the Ash'arite theology in the Maghreb. Such development shows how the Ash'arites won control over most intellectual contributions. The influence of Sanusi and the works of some other intellectuals spread over the Islamic world and reached Eastern Muslim regions such as Malaysia, Indonesia and the Archipelago of Malay in general. The journey of this development may be evaluated through the study of the general features of every period. In the first stage, however, the Ash'arite ideology was not fully developed to the point where it could set its own independent school in the Maghreb; it was limited to individual representations instead (Saghir, 2005).

The second stage of the Ash'arite official endorsement was marked by wide-spread diffusion. During that period, the principles of the new ideology were formed on a Maghrebian basis in light of the political conditions during that time and the theoretical conditions of the Maghreb surrounding the rise of the Almohads dynasty. The primary motive perhaps might have been the desire to counteract the spread of the Almoravids theology. As such, adherents to Ash'arite theology chose among their legal opinions one which states that theoretical disciplines are compulsory for every mature Muslim, male and female, and that learning Ash'arism is pre-requisite for authentic Muslim faith and beliefs; and that without it one's faith would be void. Apparently, this was made to support the ideology of the Ash'arite School and to further bring more attention to it, for the reason that the rational sciences indicated here only referred to the ideology of 'People of Truth' (ahl al-haqq) (Ihnana, 2007). People of Truth in that case represented the Almohads and their Ash'arite theology only in contrast to Almoravids and their beliefs in delegation and Anthropomorphism (al-tafwid wa al-tasim).

Political circumstances also witnessed a remarkable improvement of Ash'arite thought during the period of Almohads. The strict pre-existing condition that supreme political governance (imamship) requires Quryashite descent was loosened. This proves that the Almohads overcame the political dilemma they encountered due to accession of nonArab Berber rulers (Idrisi 1991,). This situation of tolerance and compromise lasted up until its elimination altogether from the field of Muslim theology during the time of al-Sanusi (Ihanna, 2007). Separation of Almohads from the Abbasid Caliphate and the establishment of an independent Caliphate in the Maghreb was also a serious political change. This was especially the case when the rulers were no more of Qurayshite descent, and subsequently the matter of Imam (ruler/governor) in the Ash'arite ideology became a source of embarrassment to many intellectuals and, at the same time, motivation for leniency and sometime disregard towards this condition as the Issue was unresolved through consensus, with only few scholars denying the requirement of the Qurayshte descent. Scholars in the Maghreb ignored this issue altogether and never brought back to their manuals on Islamic creed. However, separation of the problem of Imam from ideological discussion appears to have taken place during the time of Sanusi. Since then, works on Imamship usually entitled Mabhath fi al-Imamah (A study of imamah) was closer to politics than to theology. And because of this, there were a great number of political writings on Imamah (Ihanna, 2007).

However, if the first two stages of the Ash'arite development in the region, Namely the early introduction of the Ash'arites in Maghrib and that of Almohads (Ibn Tumart), were marked with significant improvement with regard to the quantity and quality of works on Ash'arite theology, then the third final Sanusi's stage was on the development of Ash'arites. Although Sanusi's period witnessed drawbacks at the political and civilizational levels, there were other signficant improvements in regards to the volume of works produced at the time, especially in the field of theology. This has helped establish the Ash'arite ideology as the official theology for people in the Maghreb until today (al-Jabiri 1987). There are, however, additional dimensions that manifest the presence of Ash'arite theology in the Maghreb. Since its beginning, Ash'arism in the Maghreb was associated with political and religious reform leading to favoring of a number of legal opinions to support its continuation in the Maghreb, and selection of legal views that complied with their ideological status and with the objective conditions encountered in their ideological conflict.

Throughout the development of Ash'arite ideology in the Maghreb, there appears to be a consensus for the positiveness of the Ash'arite theology made then compulsory on Muslim public, while imitation in theology was forbidden and imitators were seen as non-Muslims (Ayt $\mathrm{H}$ amu, 45-70-55). This was because of the fierce and sometime bloody intellectual and political conflicts arising among Ash'arites and Almoravids scholars. The Ash'arite ideology encountered systematic ideological thought which favoured the imitation of the beliefs of the companions of Prophet Muhammad while at the same time being dominant among the public (Al-Qabali, 1987). This led Ash'arite sholoars to choose among the legal Ash'arite perspective as endorsed by a number of Ash'arite scholars in the East: to force the public to learn Ash'arite theology and to force them to look into rational problems seen back then as a condition of legitimate belief.

Another serious theological problem affecting Ash'arite thought in the Maghreb was the absence of deniers of Prophethood and miracles of Prophets. This might have resulted from the nature of the religious intellectual atmosphere 
in the Maghreb, which was not exposed to the theological theses such as those of Abu 'Isa al-Warraq (d. 861), Ibn alRawandi (d.913) and others in the Muslim East (Deuraseh 2008; al-Birūni, 9: 51-100). In fact, the theological ideology of the deniers appeared in the East and lasted up until the Sixth Century, showing up and fading on numerous occasions and threatening the ideology of the Muslim masses (Amin 1961). In general Muslims sought to support their Muslim beliefs and repel disbeliefs, leading Ash'arites in the East to engage with critical theological threats and to prodice many philosophical and theological treatises on the topic of Prophethood while cautioning Muslims masses from agnosticism. In their works, the Ash'arites supported their theisis with evidences on the truth of Prophethood and miracles ('Abd alJabbar; al-Bayhaqi; al-Razi; Karmani). In the Maghreb however, the theme of Prophethood was limited to basic knowledge incumbent on every Muslim. This was because the Maghreb did not face similar threats as those arising in the Muslim East. The Maghreb writings on theology were simple and free from lengthy details except for al-Qadi Abu Bakr ibn al-'Arabi who lived in the East and was exposed to many of those theological debates and controversies (Bin Sa'id, 1997).

In each stage of development of Ash'arite theology, the main influential figures appear to be different. In the first stage, Baqillani was the main figure for the period because of the significant number of adherents of the Ash'arite ideology who were mostly his students and those who held his views and ideologies. In the second phase however, Juwayni was the most influential figure. His thoughts influenced those who were involved in the field of theology during his time. His main influence was shown in his work al-Irshad (Ihanana, 2007). The third stage however, is known as the Sanusi's period, during which Ash'arite works spread. Logic was heavily incorporated into the themes, works and treatises of theology up to the point where one would hardly distisguish theology from logic. Besides, there is no trace of philosophical impact on the Ash'arite works contrary to the writings of later Ash'arite scholars such as Fakhr al-Din alRazi in the East (Ihanana, 2007). Tracing the Ash'arite ideology in the Maghreb shows how most of the key Ash'arite representatives were able to spread their theology. Sufis also participated enthusiastically in the process of officializing the Ash 'arite dogma. Sufis however, were able to separate their practice from the developing process of Ash'arism, and hence made clear distinctions between Sufism and Ash'arism, and have as such drawn the boundaries between what is to supposed to ascetic and theological, as seen perhaps in their light treatement of the topic of the miracles of the Sufis (karamat al-Sufiyyah) in some of their theological treatises.

\section{Forging the Intellectual Unity in the Maghreb}

A number of critical factors made visible the intellectual and theological homegenity in the Maghreb. First, the Maliki School of law spread widely in the Maghreb and became dominant among other schools of law and thought. Then came the Ash'arite School which gradually spread all over the Maghreb and limited the influence of other Islamic Schools of thought. This unity in the Maghreb was further supported by the public recitation of the Qur'an according to the reading of warsh, in addition to adhering to the spiritual style of al-Junayd. The ideological poetry written in late centuries in the Maghreb prove the above. Ibn 'Ashir (d.1630) in his poetry for instance enumerates the salient features and borders of the Maghreb integration (Skali 2007). He states:

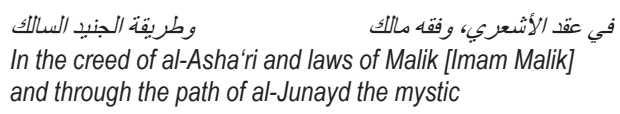

This means that the socio-religious and cultural unity of the Maghreb developed on the basis of the Ash'arite theology, the Maliki legal system, and the spiritual path of Junayd. Such an integration between Ash'arism, Malikism and Sunni Sufism led to the formation of an ideal ideological harmony in the Maghreb. As a result, the Maghreb showed resilience against a number of theological and intellectual conflicts common to other regions of the Muslim world, particularly in the East. It is interesting to note the extensive list of theological sects and affiliations that continue to form the ethnic map of Asian Arab countries. However following the Sixth Century, the group of Ibadiliyyah/lbadites, perhaps because of their overly protective social structure, was the only non-Ash'arite ideology that was resisted and who could maintain their ideology and thought though in very small area of Algeria and Libya.

The long presence of the official Ash'arite theological ideology in the Maghreb also influenced the public oral culture and tradition. As people in the Maghreb became closely attached to Ash'arite thought, they also began to reflect on its thought through prayers, sharing of wisdom and recitation of proverbs. As such, Ash'arism was seen as the idea of religious fate, infinite power of God and possibility to see the divine. This displays a sort of profound integration between the religious and political worlds. In politics, there was a clear Ash'arite ideology that spread through oral culture, one that 
stated: 'Let the ruler be sinful, better than society with no ruler', meaning that it is more bearable to have specific political order with a sinful and corrupt ruler than to have social disorder and chaos with no ruler. This explains the political stability in the region since the Eighth Century when the political scene was more settled and political entities started to form. It also explains the steady rule of the Alaouite Dynasty (1631- Present) in the Maghreb for more than five hundred years in a region with many troubles, especially with the coming of the Ottomans in the Sixteenth century, and the French occupation in the Twentieth century. The powerful Ottoman political dominance in Algeria, Tunisia, and Libya wash unable to shake the Ash'arite theologucal and intellectual structure of the Maghrebian society despite al their efforts to further support the Hanafi school of law and the Maturidi doctrine. In fact, as early as the Sixteenth Century, the Beys worked hard not only to facilitate the migration of Hanafi and Maturidi scholars to countries in the Maghreb including Libya, Tunisia, and Algeria but they also appointed jurisconsults (muftis) and judges from among the Hanafi issuing provisions and rulings according to the Hanafi school throughout the 1516-1881 CE period (Sa'd Allah, 1999). Their strenuous efforts failed to replace the Ash'arite creed and the Maliki law as sovereigns of the Maghreb.

Nevertheless, things did not remain as they were prior to the Twentieth Century during which, the appearance of what is known as the 'Islamic revival' occurred, which could have properly spell out its ideological position in the Maghreb. The twentieth century for instance has witnessed a numbers of issues including rebellion movements and political disorders affecting the legal and intellectual interpreations. Part of the problem however, might be attributed to the passive position of the Maliki and Ash'arite intellectual and historical asset. During the European occupation, people in the Maghreb passed through a vacum during which they lost significant attachment to their history and become unguarded against all sorts of religious campains and inflitrations. The Salafi Movement has also contributed to the fate of Ash'arism in the region. Beginning with the Eighteenth Century till today both Ash'arite theology and Maliki legal doctrines encountered increasing assaults on the parts of graduates of Islamic studies, particularly from the gulf. Their preoccupation to guide the mases to the purity of belief and legal practice of early Muslim generations caused states of theological, intellectual and political dis-configurations in the region. It was perhaps in light of those changes that governments of Algeria, Morroco and Tunisia appear to have realized the need to further strenghten the position of the Ash'arite theology and Malikism as a strategic religious means to secure the intellectual and religious unity of their respectives societies, and to further enhance regional harmony and stability.

\section{Conclusion}

With the rise of Ash'arite theology in the Maghreb region, the region witnessed significantly stable ideological conditions. This encouraged more writings in all different fields of Islamic knowledge and disciplines in general and specifically in the field of intellectual knowledge. Stability in the Maghreb, and freedom from sectarian divisions, also supported the growth of intellectual scholarship. Perhaps the only remaining exception are the 'Ibadites who could withstand the infiltration of pan-Maghreb Ash'arism. Ash'arism readily tolerated their presence so long the socio-religious identity and hierarchy of Maghrib. The only noticeable disturbance to its dominance during the last three decades perhaps was held by Wahabism. Throughout its diversely rich development however, the Ash'arite theological doctrine was able to mold the mind set of Muslims in the Maghreb, contributed to social dynamism, and provided society in general with the ideal model of religiosity and religious intellectual reform. Politically the Ash'arite dogma contributed effectively towards critical themes on Imamship and political governance as well as the integration of concepts of tolerance and obedience to rulers resulting thus in significant political stability as may be seen in in the political life in the Maghreb beginning with the Sixteenth Century, particularly with the Royal Alawite Family in Morocco.

\section{References}

'Alawi, Alawi, Al-Madhahib al-Islamiyyah bi-Bilad al-Maghreb, 56, 76.

'Alawi., Hasan Hafizi . 2008. Al-Madhahib al-Islamiyah bi-Bilad al-Maghreb: min al-Ta'addud ilaa al-Wahdah, (Rabat: Publication of University of Mohammad V), 43.

'Allam, AbduAllah Ali. 1964. Al-Da'wah al-Muwahidiyah bi al-Maghreb, (Cairo: Dar al-Ma'rifah), 114.

Abid al-Jabiri, Mohammad. 1987. Takwin al-Aql al-'Arabi, (Beirut: Arabic Cultural Centre \& Casablance), 120.

Abid al-Jabiri, Muhammad. 1993. Nahnu wa-al-Turath: Qira'at Mu'asirah fi Turathina al-Falsafi, (Beirut: al-Markaz al-Thaqafi al-'Arabi), $276,122$.

Abu al-Nasr, Jamil M. 1987. A History of the Maghreb in the Islamic Period, (New York: Cambridge University Press), 61.

al-'Alawi, Sa'id bin Said . 1992. Al-Khitab Al-Ash‘ari, (Beirut: Dar al-Muntakhab al-Arabi), 75, 86

Ali Foudil, Mohd. 2010. The issue of the Aghrib Mosque, Al-Chourouk newspaper, Algeria, 22 Augest 2010.

al-Maghribi, Ibn Sa'id. 1995. al-Maghreb fi Hala al-Maghreb, ed: Daif, Shawqi. 1955. I-IV (Cairo: Dar al-Ma'arif), I: 105. 
al-Majdhūb, Abd al-Aziz. 1975.Al-Sira' al-Madhhabi fi Afriqiyyah ila Qiyam al-Dawlah al-Ziriyya, (Tunis: al-Dar al-Tunisia), 127. al-Malali, Muhammad ibn Ibrahim. 2000, al-Mawahib al-Qudsiyah fi al-Sira al-Sanusiyah, transcript in the National Library of Tunisia, No.15534, 66-76.

Al-Murrakishi, Abd al-Wahid. 1999. al-Mu'jib fi Talkhis Akhbar al-Maghreb, I-II (Beirut: Dar al-Kutub al-'Ilmiyyah), I: 348.

al-Najjar, 'Abd al-Majid. 1999. al-Mahdi ibn Tumart, (Beirut: Dar al-Gharb al-Islami), 231, 233.

al-Najjar, 'Abdul-Majid. 1992. Fusūl fi Tarikh al-Fikr al-Islami fi al-Maghreb, (Beirut: Dar al-Gharb al-Islami), 87, 121.

al-Nasiri Ahmad bin Khalid, Abu al-Abbas. 1997. al-Istiqsa' li AkhbarDuwal al-Maghreb al-Aqsa, I-VIII (Morocco: Dar al-Kitab), I: 194, III, p 221

al-Qabali, Muhammad. 1987. Muraja'at hawla al-Mujtama' wa al-Thaqafa bi al-Maghreb al-Wasit, (Casablanca: Dar al-'Ilmiyyah), 65

al-Saghir, Abd al-Majid. 2005. Fi al-Hajja li Tarikh Naqdi li 'IIm al-Kalam fi al-Magrib. in: Al-ittijahat al-kalamiyyath fi al-Garb al-Islami, 'Ali al- Idrisi, (Rabat: Manshurat Kuliyyat al-Adab bi-al-Ribat), 13-26, 20, 21.

al-Șinhaji Bayaaq, Abu Bakr ibn 'Ali. 1971. Akhbar al-Mahdi Ibn Tumart wa-Bidayat Dawlat al-Muwahidin, (Ribat: Dar al-Mansur lilTiba'ah wa-al-Wiraqah), 32.

al-Tilimsani, Ibn Maryam. 1908. Al-Bustan fi Dhikr al-Awliya' wa-al-'Ulama' bi-Tilimsan, ed.Muhammad Ibn Abi Shanab, (Algeria: alMạtba'ah al-Tha'alibiyah), 211.

al-Tumami, Ibrahim. 2004. Juhūd 'Ulama' al-Maghreb fi al-Difa' ‘an 'Aqidat Ahl al-Sunah wa al-Jama'ah, (Beirut: Dar Ibn Hazm), 267.

al-Urwi, 'Abdullah. 1994. Mujmal Tarikh al-Maghreb, (Beirut/Rabat: al-Markaz al-Thaqafi al-Arabi), 101-102.

Ayt Hamu. Mohhammad. 'IIm al-Kalam fi al-Gharb al-Islamii bayn al-iqtibas wa al-khususiyah, in : Al-ittijahat al-kalamiyyah fi al-Gärb alislami, 55.

Bakhti, Jamal Allal. 2005. 'Uthman al-Salaliji wa-madhhabiyatuh al-Ash'ariyah, (Rabat: Ministry of Endowments (Awqaf), 208-254, 197.

Bel, Alfred. 1938. La religion Musulmane en Berbérie: Esquisse d'histoire et de Sociologie Religieuses, (Paris: Geuthner), 43, 122.

Bilal, Kabbache. 2007. Decree extracted from Artilce 36 of Encoutering Wahhabiyyah in the Mosques. See the Algerian al-Nahar Newspaper, July 21, 2007.

Bin Bashkwal, Abu al-Qasim Khalaf. 1966. al-Sila, I-III (Cairo: al-Dar al-Misriyya li al-Ta'lif wa al-Tarjamah), I: 567.

Ed Michaux-Bellaire, Les Habous de Tanger. 1914. Registre Officiel D'actes Et de Documents. Texte Arabe. Analyses Et Extraits, Tangier., p 166.

Elaywan, Is'id. 1996. al-Imam al-Sanūsi wa Juhuduh fi 'Ilm al-Manliq, (Algeria: Dar al-Ba'th), 45.

Faouzi, Skali. 2007. Saints et Sanctuaires de Fés, (Rabat: Marsam), 12.

Hamada, Mountasir. 2012. The Wahhabism in Morocco, Rebat, Dar Toubkal, p 34, 37, 56.

Harakat, Ibrahim, 2000. Madkhal ila Tarikh al-'Ulum bi-al-Maghreb al-Muslim hattaa al-Qarn 9/15 M, II-II ( Casablanca: Dar al-Rashad alHadithah), II: 211, 321,321,387, 418-423,424.

Hodgson, Marshall G.S. 1958. The Venture of Islam, (The Classical Age of Islam). (Chicago and London: University of Chicago Press), I: 19-20.

Ibn 'Asakir. 2001. Tabyin Kadhib al-Muftari, I-II (Beirut: Dar ibn Hazm), I: 121; Iyaa, al-Qaai. 2000. Tartib al-Madarik, II-II (Beirut: Dar alGharb al-Islami), II: 586.

Ibn Khaldun, Abdul-Rahman. 2004. al-Muqaddimah (Beirut: Dar Ibn Hazm), I: 267, 267,269.

Idrisi, Ali. 1991. al-Imamah 'inda Ibn Tumart: Dirasah Muqaranah ma'a al-Imamiyah al-Ithnay 'Ashriyyah, (Algeria:Diwan al-Mạtbu'at alJami'iilyah), 76.

Ihnana, Yusuf. 2007. Tatawwur al-Madhhab Ash‘ari fi al-Gharb al-Islami, (Rabat: Ministry of Endowments), 46, 53, 67, 71, 28, 65, 65, 68.

Iyaa, Qaai. 1982. al-Ghaniyyah- Fihrist Shuyukh al-Qaai lyaa-, ed: al-Mukhtar al-Talili, (Beirut: Dar al-Gharb al-Islami), $226-227$.

Lakhal , Sa'id. 2009 . Hatta La Yabqa al-Maghrib Hudhnan li-Dhalalat al-Wahhabiyyah wa-Makhatiriha (So that the Maghreb does not remain the safe haven for the misguidances of Wahhabism and its threats), al-Hiwar al-Mutamaddin, 2634, 2/5/2009, 10:09

O'Brien, Patrick Karl. 2010. Atlas of World History, (Oxford: Oxford University Press), 87.

Sa'd Allah, Abu al-Qasim. 1999. Tarikh al-Jaza'ir al-Thaqafi, VI-IX (Beirut, Dar al-Gharb al-Islami), VI: 54, 213.

Sallabi, Ali Muhammad. 2003. Al-Jawhar al-Thamin bi-Ma'rifat Dawlat al-Murabitin, (Cairo: Dar al-Tawzi' wa-al-Nashr al-Islamiyyah), 76.

Sidaoui, Riadh,. 2009. Algeria 1962-2008: Islamic Politics and The Military in Religion and Politics: Islam and Muslim Civilisation, by JanErik Lane and Hamadi Redissi, Ashgate, England, USA, 224-244.

Skali, Faouzi. 2007. Saints et Sanctuaires de Fés, (Rabat: Marsam), 12.

Talibi, Ammar. 1997. al-Nass al-Kamil li-Kitab al-'Awasim min al-Qawasim, (Cairo: Maktabat Dar al-Turath), 9, 54.

Yousef, Harima. The Moroccan Wahhabism between Religion and Politics, Al-Hiwar Al-Mutamadin, issue, 2419, 29-09-2008. 
